\title{
'Big'-Insulin-Like Growth Factor-II Signaling Is an Autocrine Survival Pathway in Gastrointestinal Stromal Tumors
}

\author{
Bart Rikhof, ${ }^{*}$ Winette T.A. van der Graaf, ${ }^{\dagger}$ \\ Albert J.H. Suurmeijer, ${ }^{\ddagger}$ Jaap van Doorn, ${ }^{\S}$ \\ Gert Jan Meersma, ${ }^{*}$ Patricia J.T.A. Groenen," \\ Ed M.D. Schuuring, ${ }^{\ddagger}$ Coby Meijer, ${ }^{*}$ and \\ Steven de Jong*

\begin{abstract}
From the Departments of Medical Oncology" and Pathology, University Medical Center Groningen, University of Groningen, Groningen; the Departments of Medical Oncology ${ }^{\dagger}$ and Pathology," Radboud University Nijmegen Medical Center, Nijmegen; and the Department of Metabolic and Endocrine Diseases, ${ }^{\S}$ University Medical Center Utrecht/Wilhelmina Children's Hospital, Utrecht, The Netherlands
\end{abstract}

New treatment targets need to be identified in gastrointestinal stromal tumors (GISTs) to extend the treatment options for patients experiencing failure with small-molecule tyrosine kinase inhibitors, such as imatinib. Insulin-like growth factor (IGF)-II acts as an autocrine factor in several tumor types by binding to IGF receptor type 1 (IGF-1R) and/or the insulin receptor (IR) isoform $A$. The aim of the present study was to investigate the putative role of unprocessed pro-IGFII, called 'big'-IGF-II, in GISTs. The imatinib-sensitive GIST882 and imatinib-resistant GIST 48 cell lines secrete high levels of big-IGF-II as demonstrated by ELISA and Western blotting analyses. IR isoform $A$ mRNA and protein expression, but not that of IGF-1R, was found in these KIT mutant cell lines and in KIT and platelet-derived growth factor receptor $\alpha$-mutant GIST specimens. Down-regulation of either big-IGF-II or IR affected AKT and MAPK signaling and reduced survival in both cell lines. Disruption of big-IGF-II signaling in combination with imatinib had additive cytotoxic effects on GIST882 cells. IGF-II mRNA as determined by in situ hybridization was present in $\mathbf{9 1 \%}$ of 60 primary GISTs. Immunohistochemical analysis of big-IGF-II protein expression was associated with moderate- to high-risk tumors compared with tumors with a lower risk classification $(P<0.028)$. Our data put forth the big-IGF-II/IR isoform $A$ axis as an autocrine survival pathway and potential thera- peutic target in GISTs. (Am J Pathol 2012, 181:303-312; bttp://dx.doi.org/10.1016/j.ajpath.2012.03.028)

Gastrointestinal stromal tumors (GISTs) are the most common soft tissue sarcomas of the gastrointestinal tract and are characterized by the overexpression of the receptor tyrosine kinase KIT. Various KIT genomic mutations occur in at least $80 \%$ of GISTs. In addition, approximately $5 \%$ of GISTs have mutations in the plateletderived growth factor receptor $\alpha$ (PDGFRA) gene. These mutations lead to ligand-independent activation of either KIT or PDGFRA, which is considered as an initiating step in the development of GIST. ${ }^{1}$ Although most patients with advanced GIST are successfully treated with imatinib and other small-molecule tyrosine kinase inhibitors active against KIT and PDGFRA, some patients are initially resistant to these compounds, and almost all patients finally show disease progression after an initial response. ${ }^{2}$ Therefore, new treatment targets need to be identified.

Insulin-like growth factor (IGF)-II is a regulatory polypeptide that is critical for normal growth and differentiation. In many types of cancer, IGF-II is overexpressed and is involved in tumor progression and metastasis. ${ }^{3}$ It is synthesized as a 180-amino acid pre-prohormone with a 24-amino acid signal peptide at the N-terminal end and a C-terminal extension of 89 amino acids called the Edomain. During intracellular processing, the signal peptide and the E-domain are cleaved in several steps from the precursor protein, resulting in mature IGF-II consisting of 67 amino acids (mol. wt. $\sim 7.5 \mathrm{kDa}$ ). However, many tumors have been found to secrete larger forms of IGF-II

Supported by personal grants from the Dutch Cancer Society and The Netherlands Organization for Health Research and Development (B.R.).

Accepted for publication March 29, 2012.

None of the authors disclosed any relevant financial relationships.

Supplemental material for this article can be found at http://ajp. amjapthol.org or at http://dx.doi.org/10.1016/j.ajpath.2012.03.028.

Address reprint requests to Steven de Jong, Ph.D., Department of Medical Oncology, University Medical Center Groningen, University of Groningen, Hanzeplein 1, 9713 GZ Groningen, The Netherlands. E-mail: s.de.jong@umcg.nl. 
Table 1. Primers Used for RT-PCR

\begin{tabular}{|c|c|c|c|c|c|}
\hline Gene & Forward primer & Reverse primer & $\begin{array}{c}\text { Annealing } \\
\text { temperature } \\
\left({ }^{\circ} \mathrm{C}\right)\end{array}$ & $\begin{array}{l}\text { No. of } \\
\text { RT-PCR } \\
\text { cycles }\end{array}$ & $\begin{array}{c}\text { Product } \\
\text { size } \\
\text { (bp) }\end{array}$ \\
\hline $\begin{array}{l}\text { IGF-II } \\
\text { IGF-I } \\
\text { INS (Insulin) } \\
\text { IGF-1R } \\
\text { IR* } \\
\text { GAPDH }\end{array}$ & $\begin{array}{l}\text { 5'-CTCCTGGAGACGTACTGTGCTA-3' } \\
\text { 5'-AGCAGTCTTCCAACCCAATTATTTA-3' } \\
\text { 5'-GCAGCCTTTGTGAACCAACAC-3' } \\
\text { 5'-GCCCGAAGGTCTGTGAGGAAGAA-3' } \\
\text { 5'-CTGAAGGAGCTGGAGGAGTC-3' } \\
\text { 5' -CACCCACTCCTCCACCTTTG-3' }\end{array}$ & $\begin{array}{l}\text { 5'-TCATATTGGAAGAACTTGCCCA-3' } \\
\text { 5'-AGATGCGAGGAGGACATGGT-3' } \\
\text { 5'-CGTTCCCCGCACACTAGGTA-3' } \\
\text { 5'-GGTACCGGTGCCAGGTTATGA-3' } \\
\text { 5'-CGCTGGTCGAGGAAGTGTTG-3' } \\
\text { 5' -CCACCACCCTGTTGCTGTAG-3' }\end{array}$ & $\begin{array}{l}60 \\
55 \\
60 \\
55 \\
55 \\
60\end{array}$ & $\begin{array}{l}30 \\
36 \\
36 \\
30 \\
30 \\
30\end{array}$ & $\begin{array}{c}117 \\
83 \\
71 \\
555 \\
169 / 205 \\
110\end{array}$ \\
\hline
\end{tabular}

*This primer pair detects both isoforms of the insulin receptor, resulting in PCR products of $169 \mathrm{bp}$ (isoform A) and of $205 \mathrm{bp}$ (isoform B).

Abbreviations: bp, base pair; GAPDH, glyceraldehyde-3-phosphate dehydrogenase; IGF, insulin-like growth factor; IGF-1R, IGF receptor type 1; IR, insulin receptor; RT-PCR, reverse transcription polymerase chain reaction.

(mol. wt. 10 to $18 \mathrm{kDa}$ ) that still contain at least the first 21 amino acids of the E-domain, which may be differentially glycosylated. ${ }^{4}$ These larger forms of IGF-II are called proIGF-IIE[68-88] or 'big'-|GF-II. Mature IGF-II and big-|GF-II have been shown to act as autocrine growth factors in several tumor types. They can exert their mitogenic and anti-apoptotic effects by binding to the IGF receptor type 1 (IGF-1R) and the insulin receptor (IR) isoform A. ${ }^{5}$

Recently, we have reported on the occurrence of hypoglycemia in patients with a GIST being associated with increased circulating levels of tumor-derived big-|GF-II. ${ }^{6}$ This observation prompted us to study the role of big-|GF-II as an autocrine factor in in vitro GIST model systems. We also evaluated the incidence of IGF-II expression in GIST specimens. Our findings indicate that big-IGF-II secretion by GIST provides a pro-survival signal that is relevant for the maintenance of this malignancy.

\section{Materials and Methods}

\section{Cell Culture}

The GIST cell lines GIST882 en GIST48 were kindly provided by Jonathan Fletcher (Brigham and Women's Hospital, Boston, MA). GIST882 has a homozygous KIT exon 13 mutation and was maintained in RPMI 1640 medium (Invitrogen, Praisley, UK) supplemented with 15\% (v/v) heat-inactivated fetal calf serum (Bodinco, Alkmaar, The Netherlands) and $1 \mathrm{mmol} / \mathrm{L}$ L-glutamine (Invitrogen). ${ }^{7}$ GIST48 was established from a progressive tumor during imatinib therapy, and harbors a homozygous primary KIT exon 11 mutation and a heterozygous secondary imatinib resistance mutation in exon 17 . The GIST48 cells were maintained in F-10 medium (Invitrogen) supplemented with $10 \%$ fetal calf serum and $0.5 \%(\mathrm{v} / \mathrm{v})$ mito + serum extender (VWR International, Roden, The Netherlands) and $1 \%(\mathrm{v} / \mathrm{v})$ bovine pituitary extract (VWR International). ${ }^{8}$ The rhabdomyosarcoma cell line RD (ATCC, Wesel, Germany) was cultured in DMEM high glucose (Invitrogen) supplemented with $10 \%$ fetal calf serum.

\section{$R T-P C R$}

Cell lines and frozen tumor samples were resuspended in 1 $\mathrm{mL}$ of Trizol (Invitrogen), and RNA was isolated and converted to $\mathrm{CDNA}^{9}$ For PCR, $1 \mu \mathrm{l}$ of $\mathrm{CDNA}$ was amplified using primers (primer sequences in Table 1) in a total vol- ume of $25 \mu \mathrm{L}$ using 1.25 U of Taq polymerase (Invitrogen). Universal human reference RNA (Stratagene, La Jolla, CA) was used as a positive control for IGF-I and insulin expression.

\section{Determination of IGF-// Secretion}

GIST882, GIST48, and RD cells were cultured in six-well plates to $75 \%$ confluence. After the cells were washed twice, they were cultured in $1 \mathrm{~mL}$ of cell line-specific maintenance medium for an additional 48 hours. The final numbers of cells were counted using a hemacytometer. The conditioned cell culture medium was collected, centrifuged for 10 minutes at $110 \times g$, and the supernatant stored at $-20^{\circ} \mathrm{C}$ until further analysis. IGF-II concentrations in the supernatant were determined by a nonextraction IGF-II enzyme-linked immunosorbent assay (ELISA) kit (Diagnostic Systems Laboratories, Sinsheim, Germany) according to the manufactures instructions and related to the number of cells in the culture. This ELISA does not cross-react with bovine IGF-II (according to the manufacturer and our own testing) and measures both human mature and big-IGF-II.

To determine the forms of IGF-II secreted by GIST cells by Western blotting, GIST882 and GIST48 cells were cultured under serum-free conditions in RPMI 1640 or F10 with bovine pituitary extract, respectively, supplemented with 10 $\mu \mathrm{g} / \mathrm{mL}$ of transferrin (Invitrogen), $5 \mathrm{ng} / \mathrm{mL}$ of sodium selenite (Sigma-Aldrich, Zwijndrecht, The Netherlands), $2 \mathrm{mmol} / \mathrm{L}$ L-glutamine, 0.1\% (w/v) bovine serum albumin (Invitrogen). Conditioned medium was lyophilized and reconstituted in demi-water. The total IGF-II concentration was determined by ELISA. For Western blotting, an equal volume of $2 x$ sample buffer (0.5 mol/L Tris-HCl, pH 6.8, 4\% (w/v) SDS, $20 \%$ (v/v) glycerol, $0.002 \%(\mathrm{w} / \mathrm{v})$ bromophenol blue, and $10 \%$ (v/v) 2- $\beta$-mercaptoethanol; all obtained from SigmaAldrich) was added and the samples were boiled for 10 minutes. Unconditioned serum-free medium and rhIGF-II (R\&D systems, Abingdon, UK) were processed in parallel as negative and positive controls, respectively.

\section{Western Blot Analysis}

Frozen primary GIST samples were pulverized and dissolved in ice-cold PBS. After centrifugation at 18,000 $\times g$ for 1 minute to remove debris, the supernatant was collected. The protein concentration was determined according to the Bradford method and $2 x$ sample buffer was added. Cell lines cultured in 6-well plates were serum starved for 4 hours and then incubated for 5 minutes with 
rhlGF-II (20 nmol/L) or insulin (20 nmol/L; Novo Nordisk, Alphen aan den Rijn, The Netherlands). Alternatively, cells were treated with siRNA as described below. After treatments, cells were lysed in ice cold $1 \times$ sample buffer and boiled immediately for 10 minutes. The protein concentration was determined with a detergent-compatible protein assay (Bio-Rad, Veenendaal, The Netherlands). Western blotting was performed as described previously. ${ }^{10}$ Goat anti-IGF-II (polyclonal, 1:500; R\&D Systems), rabbit antiIIE[68-88] antiserum (1:1000; WKZ6279), ${ }^{11}$ mouse antiactin (clone C4, 1:20,000; ICN Biomedicals, Zoetermeer, The Netherlands), rabbit anti-IR (polyclonal, 1:200; Santa Cruz, Heerhugowaard, The Netherlands), rabbit anti-phospho-KIT (polyclonal, 1:1000; Invitrogen), mouse anti-phospho-extracellular signal-regulated kinase-1 and -2 (ERK1/ 2)(Thr202/Tyr204) (clone E10, 1:2000; Cell Signaling Technology, Bioké, Leiden, The Netherlands), rabbit antiphospho-IGF-1R(Tyr1135/1136)/IR(Tyr1150/1151) (clone 19H7, 1:1000; Cell Signaling Technology), and rabbit antiIGF-1R, rabbit anti-phospho-AKT(Ser473), rabbit anti-AKT, and rabbit anti-ERK1/2 (polyclonal, 1:1000; Cell Signaling Technology) served as primary antibodies.

\section{Flow Cytometry}

IGF-1R and IR membrane expression were determined by flow cytometry, ${ }^{10}$ using phycoerythrin-conjugated mouse anti-IGF-1R (clone 1H7, 1:10; BD Pharmingen, Alphen aan den Rijn, The Netherlands) and anti-IR (clone 3B6, 1:10; BD Pharmingen) monoclonal antibodies. Phycoerythrin-conjugated mouse $\operatorname{IgG}_{1 \kappa}$ (BD Pharmingen) served as an isotype control.

\section{Short Interference RNA Transfections}

Synthetic short interference RNA (siRNA) duplexes were purchased from Eurogentec (Maastricht, The Netherlands). The sense sequence for IGF-II siRNA was 5'GCAUCUUCAAACAUGUACAAAdTdT-3' and the antisense was 5'-UUUGUACAUGUUUGAAGAUGCdTdT-3' . The sense sequence for IR was 5'-GGCUCCUUCGGCAUGGUGUAUdTdT-3' and the antisense was 5'AUACACCAUGCCGAAGGAGCCdTdT-3'. Plated cells were transfected using siRNAs (final concentration 50 $\mathrm{nmol} / \mathrm{L}$ ) with oligofectamine (Invitrogen) and OptiMEM (Invitrogen) according to the manufacturer's instructions. After 4 hours' incubation, the medium was changed to complete culture medium. As a negative control, scrambled, nonsilencing siRNA (Eurogentec) was used.

\section{Cell Viability and Apoptosis Assays}

Cells were plated at $3 \times 10^{4}$ cells per well in 96-well plates and cultured in normal medium for 2 days before siRNA transfection or treatment with the IR tyrosine ki-

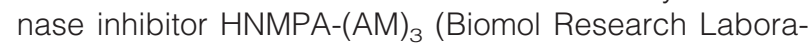
tories, Plymouth Meeting, PA). ${ }^{12}$ Seventy-two hours after transfection or treatment, cell viability was assessed with thiazolyl blue tetrazolium bromide (MTT). ${ }^{10}$ Alternatively, 24 hours after siRNA transfection, GIST882 cells were washed with and incubated in RPMI 1640 supplemented with transferrin, sodium selenite, L-glutamine, and bovine serum albumin, as described above. After 48 hours' incubation under serum-free conditions, cell viability was evaluated with MTT. To evaluate the combined effects of KIT inhibition and either IGF-II or IR silencing, cells were incubated with 0.05 or $0.1 \mu \mathrm{mol} / \mathrm{L}$ imatinib for 48 hours, starting 24 hours after siRNA transfections. All MTT assays were performed three times in quadruplicate. To evaluate apoptosis, $1.5 \times 10^{4}$ cells per well in 96-well plates were treated with siRNA. Apoptosis was determined 48 and 72 hours after siRNA transfection with the acridine orange assay. ${ }^{13}$ All apoptosis assays were performed in duplicate and repeated three times.

\section{Tissue Collection and Tissue Microarray Construction}

Sixty primary paraffin-embedded tumor tissues of GISTs and seven frozen GIST samples were retrieved from the files of the Department of Pathology of the University Medical Center Groningen. All tumors were surgically resected between 1985 and 2006 and diagnosed as described previously. ${ }^{13}$ Tumors were categorized into risk groups, based on tumor size, mitotic index, and primary localization of the tumor, according to the recently modified consensus classification for prediction of metastatic behavior. ${ }^{14}$ Mutation analysis of KIT exons 9, 11,13 , and 17, and PDGFRA exons 12, 14 and 18 was performed as described previously. ${ }^{6}$ Patient and tumor characteristics are summarized in Table 2. From each individual paraffin-embedded tumor specimen, three distinct, representative 0.6-mm tissue cores were taken and transferred to a standard-size recipient paraffin block to create a tissue microarray. ${ }^{13}$ All tumor samples were handled according to the guidelines of the Dutch Federation of Biomedical Scientific Societies (FMWV) as described in "Code Proper Secondary Use of Human Tissue."

\section{RNA in Situ Hybridization and Immunohistochemistry}

The methods used for in situ hybridization with digoxigenin-labeled hIGF-II complementary RNA probes have been described previously. ${ }^{15} \beta$-Actin digoxigenin-labeled complementary RNA probes were used to evaluate the preservation of RNA in the tissue specimens studied. Negative controls for in situ hybridization were prepared using sense probes. Immunohistochemistry was performed as described previously. ${ }^{13}$ Antigen retrieval was performed either by boiling slides in a microwave in 0.01 mol/L citrate buffer ( $\mathrm{pH}$ 6.0) for 15 minutes or by autoclaving in blocking solution (2\% (w/v) blocking reagent (Roche Diagnostics, Mannheim, Germany) and 0.2\% $(\mathrm{w} / \mathrm{v})$ SDS in maleic acid buffer $\left(\mathrm{pH} \mathrm{6.0)}\right.$ ) at $115^{\circ} \mathrm{C}$ for three times, 5 minutes each for the detection of IIE[68-88] or total IGF-II, respectively. Primary antibodies were rabbit anti-IIE[68-88] antiserum (1:200; WKZ6279) ${ }^{11}$ and goat anti-IGF-II (1:50; R\&D Systems). As a negative control, a serial section was processed by replacement of primary antibody with either preimmune rabbit antiserum or normal goat IgG. For both immunohistochemistry and in situ 
Table 2. Patient $(n=59)$ and Tumor $(n=60)$ Characteristics*

\begin{tabular}{|c|c|}
\hline & $n(\%)$ \\
\hline \multicolumn{2}{|l|}{ Sex } \\
\hline Male & $28(47)$ \\
\hline Female & $31(53)$ \\
\hline Age, years, median (range) & $66(24-87)$ \\
\hline \multicolumn{2}{|l|}{ Risk classification } \\
\hline Benign & $4(7)$ \\
\hline Very low risk & $7(12)$ \\
\hline Low risk & $17(28)$ \\
\hline Moderate risk & $14(23)$ \\
\hline High risk & $18(30)$ \\
\hline \multicolumn{2}{|l|}{ Primary site } \\
\hline Stomach & $32(53)$ \\
\hline Small intestine & $23(38)$ \\
\hline Colon & $4(7)$ \\
\hline Unknown & $1(2)$ \\
\hline \multicolumn{2}{|l|}{ Histology } \\
\hline Spindle cell & $48(80)$ \\
\hline Epithelioid & $7(12)$ \\
\hline Mixed & $5(8)$ \\
\hline \multicolumn{2}{|l|}{ Tumor size } \\
\hline$\leq 10 \mathrm{~cm}$ & $41(68)$ \\
\hline$>10 \mathrm{~cm}$ & 19 (32) \\
\hline \multicolumn{2}{|l|}{ Mitotic figures } \\
\hline$\leq 5$ per $50 \mathrm{HPF}$ & $45(75)$ \\
\hline$>5$ per $50 \mathrm{HPF}$ & $15(25)$ \\
\hline \multicolumn{2}{|l|}{ Mutations } \\
\hline KIT exon 9 & $6(10)$ \\
\hline KIT exon 11 & $31(52)$ \\
\hline PDGFRA exon 12 & $2(3)$ \\
\hline PDGFRA exon 18 & $7(12)$ \\
\hline No mutations found & $8(13)$ \\
\hline Not evaluable & $6(10)$ \\
\hline
\end{tabular}

*One patient had two primary GISTs, which were a high-risk epithelioid gastric tumor with a PDGFRA exon 18 mutation and a low-risk spindle cell small intestine tumor with a KIT exon 11 mutation, respectively.

HPF, high-power fields; PDGFRA, platelet-derived growth factor receptor $\alpha$.

hybridization, normal tissue samples derived from first-trimester human placenta served as positive controls. ${ }^{16} \mathrm{Re}-$ sults for immunohistochemistry and in situ hybridization were scored independently in a semiquantitative fashion for intensity of staining by two observers (B.R. and A.J.H.S). Tissue cores from one tumor were judged to be positive when there was a clear cellular cytoplasmic staining (ie, comparable or more intense staining than placenta) in at least two of the three cores. Tumors with fewer than two assessable cores were excluded from the analysis.

\section{Statistical Analysis}

Student's $t$-test was used to analyze the differences between groups. Associations between IGF-II expression and tumor characteristics were evaluated by the $\chi^{2}$ or Fisher's exact test, where appropriate. A two-tailed $P$ value of $<0.05$ was considered to be significant.

\section{Results}

\section{Big-IGF-II Secretion by GIST Cell Lines}

IGF-II expression was evaluated in imatinib-sensitive GIST882 cells and in imatinib-resistant GIST48 cells. As shown in Figure 1A, both GIST cell lines expressed IGF-II mRNA equally to the RD rhabdomyosarcoma cell line that served as a positive control. ${ }^{17}$ Furthermore, the expression of IGF-II mRNA in the GIST cell lines was comparable to those found in the various GIST samples and also to the expression in a primary GIST cell culture. No IGF-I or insulin mRNA expression could be detected in GIST882 and GIST48, indicating that IGF-II is the only IGF ligand that is significantly expressed by these cell lines (Figure 1B). After culturing the cells for $48 \mathrm{~h}$, both GIST cell lines secreted significant amounts of IGF-II into the culture medium, which largely exceeded the IGF-II production by the RD control cell line (Figure 1C). IGF-II was predominantly secreted as high-molecular-weight forms

A

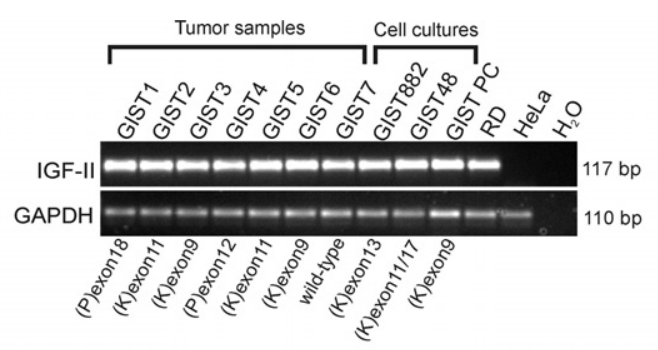

B
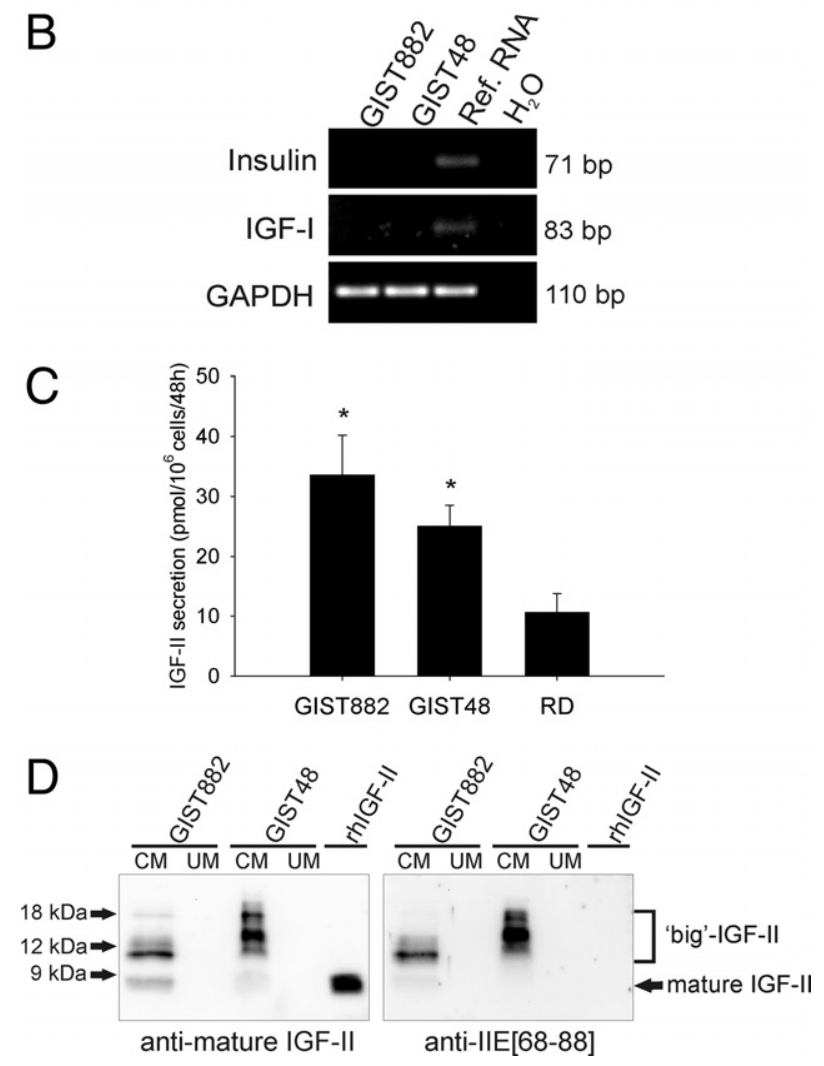

Figure 1. IGF-II expression and secretion by GIST cell lines. A: IGF-II mRNA expression in GIST samples and cell cultures with RT-PCR. RD was used as a positive control and HeLa was used as a negative control. ${ }^{41}$ GIST PC is a primary cell culture (passage 3 ) with a KIT exon 9 mutation established from a tumor that was progressive during imatinib therapy. KIT $(\mathrm{K})$ and PDGFRA (P) mutations are indicated for each GIST. GAPDH was used as a loading control. B: Insulin and IGF-I mRNA expression in GIST cell lines. Human reference RNA served as a positive control. C: Cells were cultured for 48 hours, and total IGF-II secretion (both mature and big-IGF-II) was measured by ELISA. RD served as a positive control. ${ }^{*} P<0.01$ compared with RD. D: Lyophilized serum-free conditioned medium (CM) and unconditioned medium (UM) obtained from GIST882 and GIST48 were subjected to Western blotting. Membranes were probed with antibodies against mature IGF-II and IIE[68-88]. RhIGF-II served as a positive control for mature IGF-II immunoblotting. 
containing the IIE[68-88] domain peptide of pro-IGF-II, which can be differentially glycosylated. ${ }^{18}$ GIST882 secreted mainly $\sim 11 \mathrm{kDa}$ big-IGF-II and two other less abundant high-molecular-weight forms of $\sim 12$ and $\sim 18$ $\mathrm{kDa}$. In addition, a faint band of $\sim 8-\mathrm{kDa}$ was observed, corresponding to fully processed IGF-II. GIST48 only produced big-IGF-II and at least three different forms between $\sim 12$ and $18 \mathrm{kDa}$ were detected (Figure 1D).

\section{IGF-1R and IR Expression in GIST Specimen and Cell Lines}

The expression of the cognate receptors of big-IGF-II was evaluated in tumor samples and GIST cell cultures (Figure 2, $A$ and $B$ ). In six of the seven tumor samples, all harboring mutated KIT or PDGFRA, neither IGF-1R

A
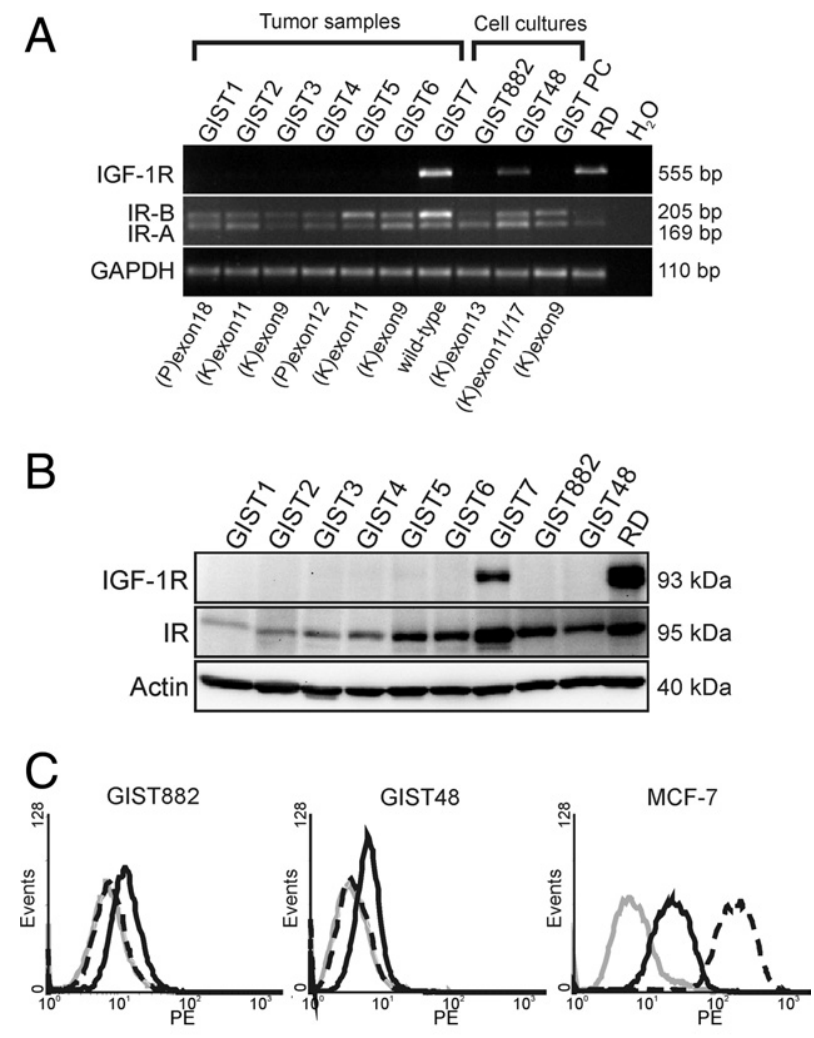

D

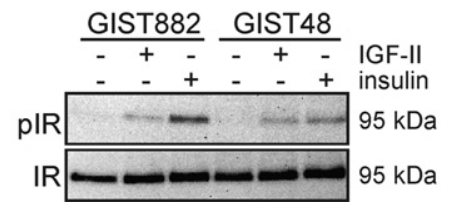

Figure 2. IGF-1R and IR expression in GIST. A: IGF-IR and IR mRNA expression in GIST samples and cell lines with RT-PCR. The primer pair for the IR detects both isoforms reflecting isoform A (IR-A) as a 169-bp band and isoform B (IR-B) as a 205-bp band. RD was used as a positive control. KIT (K) and PDGFRA (P) mutations are indicated for each GIST. GAPDH was used as a loading control. B: Western blot analysis of IGF-1R and IR expression in GIST samples and cell lines, and RD cells (positive control). Actin served as a loading control. C: Analysis of IGF-1R and IR membrane expression by flow cytometry. The gray line represents the IgG control, the black line the anti-IR antibody, and the black dotted line the anti-IGF-1R antibody. MCF-7 breast carcinoma cells were used as a positive control. D: Serum starved cells were stimulated with $20 \mathrm{nmol} / \mathrm{L}$ rhIGF-II or insulin for 5 minutes. IR phosphorylation was evaluated with Western blotting.
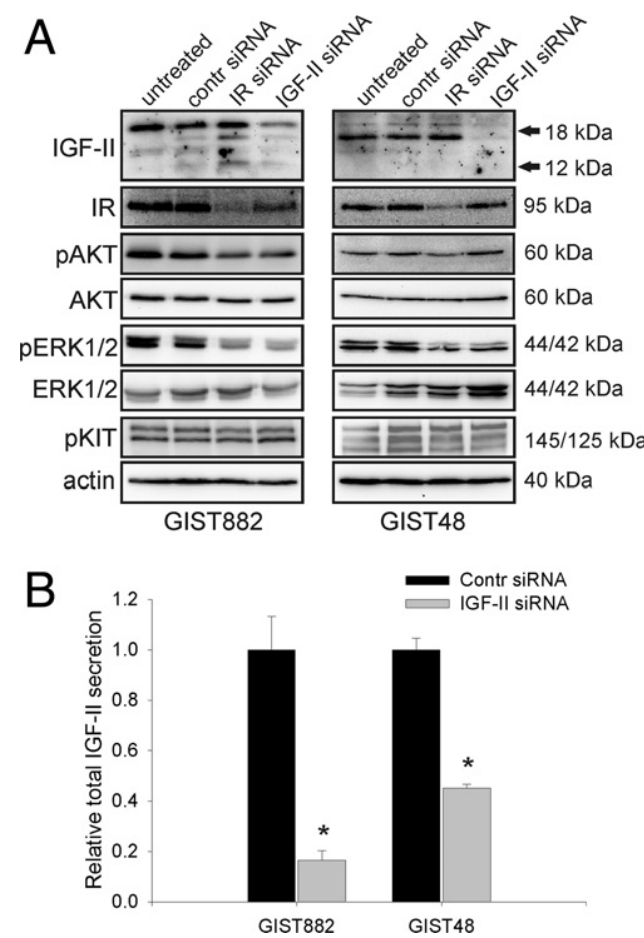

Figure 3. Effects of down-regulation of IGF-II or IR on downstream signaling. A: GIST cells were treated with either scrambled control siRNA or siRNA directed against IGF-II or IR. IR and IGF-II down-regulation and changes in phosphorylation of AKT, ERK1/2 and KIT were investigated with immunoblotting 48 hours after siRNA treatment. Actin served as a loading control. B: Twenty-four hours after siRNA transfection, cells were washed and incubated for 48 hours in maintenance culture medium. Total IGF-II concentrations were determined with ELISA and adjusted to the number of cells. The relative (ie, normalized to transfections with scrambled siRNA) IGF-II secretion after siRNA transfection was calculated for each cell line. Data represent the mean values $( \pm S D)$ of three independent experiments. ${ }^{*} P<0.01$ compared with scrambled control siRNA.

mRNA nor protein could be detected. Only the tumor with wild-type KIT and PDGFRA showed significant expression of IGF-1R mRNA and protein. Among the three GIST cell cultures, only GIST48 expressed IGF-1R mRNA, albeit at a relatively low level compared with the positive tumor. No IGF-1R protein could be detected in GIST48 or the other GIST cell cultures. In contrast, all GIST tissue samples and cell cultures expressed mRNA of both isoforms $A$ and $B$ of IR (Figure $2 A$ ), and expressed IR protein (the antibody used did not discriminate between both isoforms; Figure 2B). IR was expressed at the cell surface of the GIST882 and GIST48 cell lines. No IGF-1R membrane expression could be detected in these GIST cell lines in contrast to the highly positive control MCF-7 (Figure 2C). Stimulation with rhIGF-II or insulin induced phosphorylation of IR in GIST cells (Figure 2D).

\section{Effects of Big-/GF-II Signaling Inhibition}

The role of big-IGF-II secretion by GIST cells was further investigated using siRNA strategies to evaluate the effects of IGF-II and IR silencing. The expression of both IGF-II and IR could be effectively down-regulated with siRNA in GIST882 and GIST48 (Figure 3A). Fur- 
A

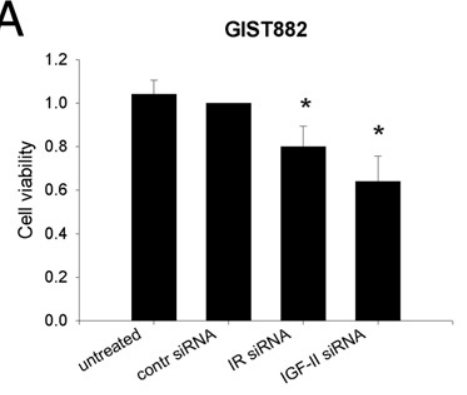

C

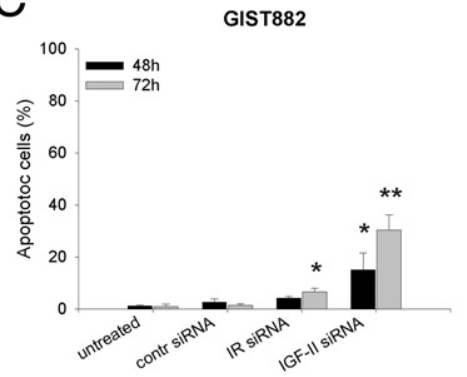

GIST48

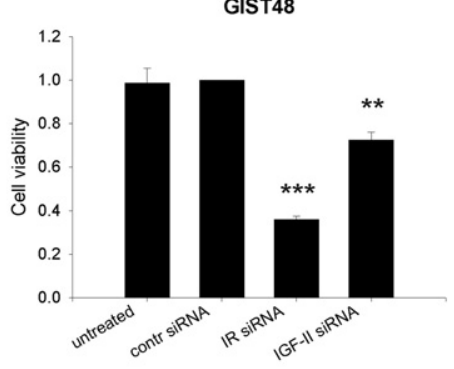

GIST48

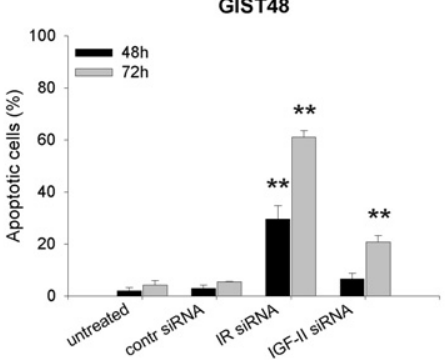

B

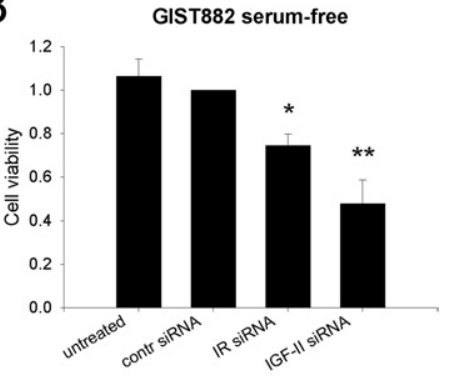

D

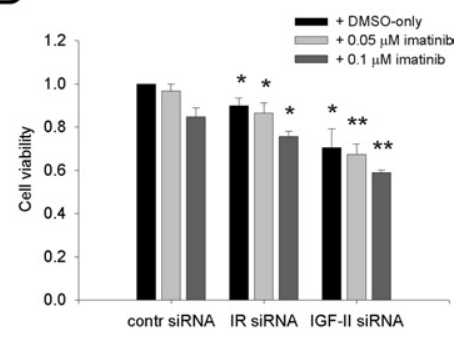

Figure 4. Effects of IGF-II and IR down-regulation on cellular survival. A: The impact of IR and IGF-II down-regulation on cell viability was determined in GIST cells 72 hours after siRNA transfection with MTT. The data were normalized to scrambled siRNA-treated control cells. B: GIST882 cells were switched to serum-free medium 24 hours after siRNA transfection and cell viability was determined with MTT after an additional 48 hours. C: The apoptotic response after siRNA treatment was determined in GIST cells with acridine orange apoptosis assays 48 and 72 hours after transfection. D: IR or IGF-II siRNA transfection of GIST882 was combined with imatinib treatment and cell viability was determined with MTT. The data were normalized to scrambled siRNA/DMSO-treated control cells. All data represent the mean values $( \pm \mathrm{SD})$ of three independent experiments. ${ }^{*} P<0.05$, ${ }^{* *} P<0.01$ and ${ }^{* * * *} P<0.001$ compared with scrambled control siRNA.

thermore, a marked reduction in the secretion of total IGF-II could be observed for both cell lines after IGF-II siRNA transfection (Figure 3B). In both cell lines, downregulation of either IGF-II or IR caused a reduction in ERK1/2 phosphorylation. Transfection of GIST882 and GIST48 cells with IR siRNA in both cases reduced AKT phosphorylation. Only in GIST882 cells was the same phenomenon seen with IGF-II siRNA. IR or IGF-II siRNA transfection did not influence KIT phosphorylation in both cell lines (Figure 3A).

Treatment with IGF-II siRNA caused a reduction in cell viability with $\sim 30 \%$ to $35 \%$ that was nearly similar for GIST882 and GIST48. For both cell lines, down-regulation of IR expression also decreased the viability of the cells, but the effect was most pronounced in GIST48 (Figure 4A). The GIST882 cell line has the capacity to survive and even to grow in serum-free medium (data not shown). This may be due to an autocrine action of big-IGF-II on IR. To investigate this possibility, the same experiments with siRNA were performed with GIST882 but now under serum-free conditions. A slightly larger effect of IGF-II siRNA on the cell viability of GIST882 cells was observed under serum-free conditions compared with the viability of these cells when cultured in serum-containing medium (Figure 4, A and B). For both cell lines, transfection with IGF-II siRNA resulted in a significant proportion of apoptotic cells after $48 \mathrm{~h}$, which had further increased after 72 hours. Silencing of the expression of IR for 48 hours resulted in a marked induction of apoptosis in GIST48 cells only (Figure 4C). The simultaneous treatment with the KIT tyrosine kinase inhibitor imatinib and transfection of the cells with either IGF-II or IR siRNA had an additive effect on cell viability of the imatinib-sensitive GIST882 cells (Figure 4D).

In addition to the siRNA approach, the effects of HNMPA- $(\mathrm{AM})_{3}$, a well-known IR tyrosine kinase inhibitor, was evaluated. HNMPA- $(\mathrm{AM})_{3}$ decreased cell viability in GIST882 and GIST48, the latter being more sensitive to this compound, which is in line with the IR silencing experiments (Figure 5). The IC50 values of the GIST cell

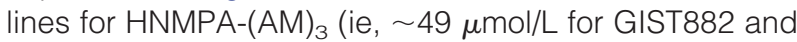
$\sim 37 \mu \mathrm{mol} / \mathrm{L}$ for GIST48) were in accordance with the concentrations that are commonly used for this compound to target specifically the insulin receptor. ${ }^{12,19,20}$

\section{(Big-)/GF-II Expression in GIST Specimen}

For a large cohort of paraffin-embedded GIST specimens, the expression of IGF-II in relation to tumor characteristics was investigated. Of 57 evaluable primary tumors, 52 (91\%) were positive for IGF-II mRNA as revealed by in situ hybridization (see Supplemental Figure S1, A and D at http://ajp.amjpathol.org). All four benign tumors and one high-risk tumor were negative for IGF-II mRNA. To investigate (big-)IGF-II expression at the protein level, immunohistochemistry with two different antibodies, an antibody raised against the IIE[68-88] domain peptide of pro-IGF-II and an antibody against fully processed IGF-II (ie, detecting both mature and high-molecular-weight forms of IGF-II), was performed (see Supplemental Figure S1, B, C, E, and F at http://ajp. amjpathol.org). Of 56 evaluable primary tumors, 36 (64\%) stained positive for IIE[68-88], and 17 of 53 evaluable primary tumors (32\%) showed positive staining for total 

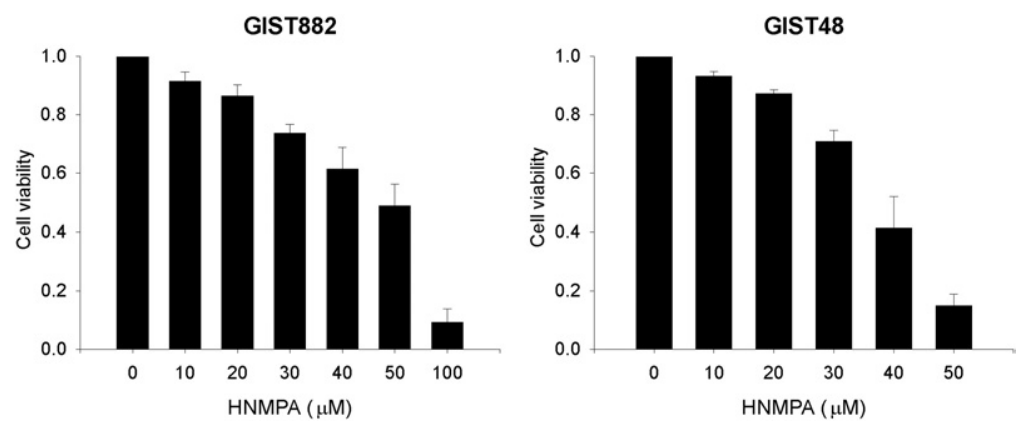

Figure 5. Effects of insulin receptor inhibition by the tyrosine kinase inhibitor HNMPA-(AM) ${ }_{3}$ on GIST cell viability. Viability was determined 72 hours after treatment with HNMPA-(AM) $)_{3}$ with MTT. The data were normalized to untreated (ie, DMSO-only-treated) controls. Data are shown as mean values $( \pm \mathrm{SD})$ of three independent experiments.

IGF-II (Table 3). All tumors positive for total IGF-II were also positive for IIE[68-88], except for one. With both antibodies, a more frequent expression of (big-)|GF-II was observed in moderate and high-risk tumors (ie, tumors with the highest malignant potential) compared with tumors with a lower risk classification $(P=0.028$ and $P=$ 0.019 , respectively)(Table 3).

\section{Discussion}

KIT and PDGFRA gain-of-function mutations are found in the vast majority of GISTs. These mutations are considered as initiating steps in the development of a GIST. Additional oncogenic events could then contribute to the malignant outgrowth of GIST. ${ }^{1}$ The identification of critical pathways that cooperate with oncogenic KIT and PDGFRA signaling in the development of a malignant GIST could be useful for the development of new therapeutics for the treatment of this cancer. The existence of additional KIT signaling-dependent and KIT signaling-independent pathways has been implied in GIST tumors as well as in GIST cell lines. ${ }^{21,22}$ We have previously reported that big-IGF-II is expressed in GISTs. ${ }^{6}$ Because the IGF signaling system is involved in the pathogenesis of several sarcoma (sub)types, ${ }^{5}$ the purpose of this study was to investigate the putative biological role of big-IGF-II in GIST.

We demonstrated that IGF-II is actively secreted by GIST cells in vitro, predominantly as big-IGF-II. These results supplement our recent findings that increased plasma levels of big-IGF-II frequently occur in GIST patients. This is likely due to excessive production of big-IGF-II by tumor tissue which may finally result in the induction of fasting hypoglycemia. ${ }^{6}$ Many tumors, including sarcoma cells of different origin, have been shown to secrete increased amounts of incompletely processed forms of pro-IGF-II that still contain the first 21 amino acids of the E-domain. The latter peptide may be differentially $O$-glycosylated leading to the size heterogeneity of big-IGF-II as we also observed for the cultured GIST cells in the present study. ${ }^{4,23}$ Similar to mature IGF-II, big-IGF-II is able to activate IGF-1R and

Table 3. IGF-II Expression and Tumor Characteristics

\begin{tabular}{|c|c|c|c|c|}
\hline & \multicolumn{2}{|c|}{ Pro-IGF-IIE[68-88] positive } & \multicolumn{2}{|c|}{ Total IGF-II positive } \\
\hline & $n(\%)$ & $P^{\star}$ & $n(\%)$ & $P$ \\
\hline All primary tumors & $36 / 56^{\dagger}(64)$ & & $17 / 53(32)$ & \\
\hline \multicolumn{5}{|l|}{ Risk category ${ }^{\ddagger}$} \\
\hline Benign/(very) low & $12 / 25(48)$ & 0.028 & $3 / 22(14)$ & 0.019 \\
\hline Moderate/high & $24 / 31(77)$ & & $14 / 31(45)$ & \\
\hline \multicolumn{5}{|l|}{ Primary site } \\
\hline Stomach & 16/31 (52) & 0.022 & 2/28 (7) & $<0.001$ \\
\hline Small intestine/colon & 20/24 (83) & & 15/24 (63) & \\
\hline \multicolumn{5}{|l|}{ Histology } \\
\hline Spindle cell & 26/44 (59) & 0.18 & $11 / 41(27)$ & 0.17 \\
\hline Epithelioid/mixed & 10/12 (83) & & $6 / 12(50)$ & \\
\hline \multicolumn{5}{|l|}{ Tumor size } \\
\hline$\leq 10 \mathrm{~cm}$ & 22/38 (58) & 0.23 & 9/34 (26) & 0.36 \\
\hline$>10 \mathrm{~cm}$ & 14/18 (78) & & 8/19 (42) & \\
\hline \multicolumn{5}{|l|}{ Mitotic figures } \\
\hline$\leq 5 / 50 \mathrm{HPF}$ & $25 / 42(60)$ & 0.33 & $9 / 39(23)$ & 0.042 \\
\hline$>5 / 50 \mathrm{HPF}$ & $11 / 14(79)$ & & $8 / 14(57)$ & \\
\hline \multicolumn{5}{|l|}{ Mutation } \\
\hline KIT exon 11 & $16 / 29^{\S}(55)$ & 0.14 & $5 / 26(19)$ & 0.066 \\
\hline No KIT exon 11 & $17 / 22(77)$ & & 10/22 (45) & \\
\hline
\end{tabular}

${ }^{*} P$ values are derived from the $\chi^{2}$ or Fisher's exact test, where appropriate.

†Number of evaluable cases (tumors with less than two evaluable cores were excluded from the analysis).

${ }^{\ddagger}$ Risk group classification is based on size, mitotic index and primary localization of the tumor. ${ }^{13}$

§Tumors not evaluable for mutation analysis were not included in this analysis.

HPF, high-power fields; IGF, insulin-like growth factor. 
IR isoform A. ${ }^{5}$ Indeed, big-IGF-II appeared to be a potent protein capable of providing an autocrine signal in GIST.

In several sarcoma types such as rhabdomyosarcoma, synovial sarcoma, and osteosarcoma, IGF-II acts as an autocrine growth and survival factor. ${ }^{17,24,25}$ IGF-II is involved in the pathogenesis of these tumors, among other oncogenic events, by signaling through IGF-1R. Recently it has been demonstrated that a subgroup of GISTs without KIT and PDGFRA mutations, so-called wild-type GISTs, strongly express IGF-1R. ${ }^{26}$ Also in rarely occurring pediatric GIST, typically associated with wild-type tumors, markedly increased IGF-1R mRNA levels have been observed. ${ }^{27,28}$ The association of IGF-1R expression with IGF1R gene amplification in wild-type tumors ${ }^{26}$ could not be confirmed by others. ${ }^{28,29}$ Indeed, in the wild-type GIST specimen that we investigated, we also encountered significant IGF-1R expression at both the mRNA and protein levels. The reported expression of IGF-1R in mutated GIST, however, is not corroborated by our study. ${ }^{26,30}$ In this limited cohort of KIT or PDGFRA mutated GISTs, IGF-IR expression appeared to be undetectably low. Our data are nevertheless consistent with those very recently reported by Janeway et al and Pantaleo et al. ${ }^{28,29}$ The IR (isoform A), as an alternative highaffinity receptor for IGF-II, was actually detectable in tumor specimens of our cohort of mutated GISTs, suggesting that this receptor is the most likely candidate for autocrine big-IGF-II signaling. ${ }^{31}$

To inhibit autocrine big-IGF-II signaling in GIST cell lines, we used siRNA against either IGF-II or IR. For both cell lines, the reduction in cell viability following down-regulation of IGF-II or IR expression with siRNA was more or less in the same order of magnitude as the extent of induction of apoptosis, suggesting that autocrine big-IGF-II is mainly involved in eliciting an antiapoptotic survival signal rather than a proliferation stimulus. Interestingly, GIST48 cells were highly sensitive toward IR silencing. This phenomenon could be due to differences in the cellular context of insulin receptor signaling between GIST48 and GIST882 cells or (partial) dependence on an exogenous IGF ligand (for example, insulin) that is present in the enriched medium in which these cells are cultured. In both cell lines, down-regulation of IGF-II expression resulted in a markedly decreased phosphorylation of ERK, whereas phosphorylation of AKT was affected to a variable and much lesser extent. Recent studies have shown that the phosphatidylinositol-3-kinase (PI3K)/AKT pathway is an important survival pathway in several GIST cell lines, including GIST882 and GIST48. Specific inhibition of the mitogen-activated protein kinase (MAPK)/ ERK pathway, however, also reduced survival, albeit to a lesser extent, suggesting that both the PI3K/AKT and the MAPK/ERK pathway are involved in the survival of GIST cells. ${ }^{32}$ It has been reported that the MAPK/ERK pathway in GIST cells, in contrast to the PI3K/AKT pathway, is only partially, or not at all, dependent on activated $\mathrm{KIT}{ }^{33,34}$ This implies that stimulation of other tyrosine kinase receptors, for instance via the big-IGFII/IR autocrine loop, contributes to the activation of intracellular signaling pathways in GIST.

Our results imply an association between big-IGF-II protein expression and the potential aggressive behavior of GISTs. Several reports have suggested a relation between IGF-II expression and decreased patient survival. $^{30,35}$ Recent studies showed that minute (1 to 10 $\mathrm{mm}$ ) GIST-like lesions are a common finding in the stomach of the adult population. In the majority of these lesions, KIT or PDGFRA mutations were found. ${ }^{36-38}$ These findings suggest that GISTs could arise from premalignant lesions that are initially caused by KIT or PDGFRA mutations but that require additional oncogenic events. In our study, only a very small number of GISTs were classified as benign. ${ }^{14}$ Three of these tumors were even smaller than $10 \mathrm{~mm}$, and in each of these tumors, a KIT or PDGFRA mutation was detected (data not shown). We noticed that all four benign tumors did not show any detectable IGF-II mRNA expression, in contrast to tumors of the other risk groups except for one high-risk tumor. Together with our in vitro findings, this suggests that gain of IGF-II (over-)expression could be an additional oncogenic event contributing to the malignant potential of GIST.

From a therapeutic point of view for those (wild-type) GISTs expressing IGF-1R, inhibition of this receptor would be an attractive option as several humanized monoclonal antibodies are currently being tested in clinical studies. ${ }^{39}$ Blocking of IR would be an interesting option in mutant GISTs, although the induction of hyperglycemia in patients with this strategy could be of concern. Alternatively, big-IGF-II could be a direct target for therapy in both imatinib-sensitive and imatinibresistant wild-type and mutant GISTs. IGF-II-neutralizing antibodies have been developed but are not yet used in clinical settings. ${ }^{40}$ However, based on our results, big-IGF-II neutralizing antibodies may have even more tumor-selective properties.

In conclusion, we showed that IGF-II is commonly expressed in GIST. Our data suggest that secreted big-IGF-II is involved in the pathogenesis of GIST by providing a pro-survival signal in an autocrine manner. Targeting its receptors or directly neutralizing the action of big-IGF-II might be attractive new therapeutic options in the fascinating area of GIST treatment, still being the model for targeted therapy in the 21st century.

\section{Acknowledgments}

The authors thank Tineke van der Sluis and Phuong Le for technical assistance.

\section{References}

1. Corless CL, Fletcher JA, Heinrich MC: Biology of gastrointestinal stromal tumors. J Clin Oncol 2004, 22:3813-3825 
2. Gastrointestinal Stromal Tumor Meta-analysis Group: Comparison of two doses of imatinib for the treatment of unresectable or metastatic gastrointestinal stromal tumors: a meta-analysis of 1,640 patients. J Clin Oncol 2010, 28:1247-1253

3. Toretsky JA, Helman LJ: Involvement of IGF-II in human cancer. J Endocrinol 1996, 149:367-372

4. De Groot JW, Rikhof B, Van Doorn J, Bilo HJ, Alleman MA, Honkoop $\mathrm{AH}$, Van der Graaf WT: Non-islet cell tumour-induced hypoglycaemia: a review of the literature including two new cases. Endocr Relat Cancer 2007, 14:979-993

5. Rikhof B, De Jong S, Suurmeijer AJ, Meijer C, Van der Graaf WT: The insulin-like growth factor system and sarcomas. J Pathol 2009, 217 : 469-482

6. Rikhof B, Van Doorn J, Suurmeijer AJ, Rautenberg MW, Groenen PJ, Verdijk MA, Jager PL, De Jong S, Gietema JA, Van der Graaf WT: Insulin-like growth factors and insulin-like growth factor-binding proteins in relation to disease status and incidence of hypoglycaemia in patients with a gastrointestinal stromal tumour. Ann Oncol 2009 , 20:1582-1588

7. Tuveson DA, Willis NA, Jacks T, Griffin JD, Singer S, Fletcher CD, Fletcher JA, Demetri GD: STI571 inactivation of the gastrointestinal stromal tumor c-KIT oncoprotein: biological and clinical implications. Oncogene 2001, 20:5054-5058

8. Bauer S, Yu LK, Demetri GD, Fletcher JA: Heat shock protein 90 inhibition in imatinib-resistant gastrointestinal stromal tumor. Cancer Res 2006, 66:9153-9161

9. Van der Deen M, De Vries EG, Visserman H, Zandbergen W, Postma DS, Timens W, Timmer-Bosscha $\mathrm{H}$ : Cigarette smoke extract affects functional activity of MRP1 in bronchial epithelial cells. J Biochem Mol Toxicol 2007, 21:243-251

10. De Groot DJ, Timmer T, Spierings DC, Le TK, De Jong S, De Vries EG: Indomethacin-induced activation of the death receptor-mediated apoptosis pathway circumvents acquired doxorubicin resistance in SCLC cells. Br J Cancer 2005, 92:1459-1466

11. Van Doorn J, Hoogerbrugge CM, Koster JG, Bloemen RJ, Hoekman K, Mudde AH, Van Buul-Offers SC: Antibodies directed against the $E$ region of pro-insulin-like growth factor-II used to evaluate non-islet cell tumor-induced hypoglycemia. Clin Chem 2002, 48:1739-1750

12. Saperstein R, Vicario PP, Strout HV, Brady E, Slater EE, Greenlee WJ, Ondeyka DL, Patchett AA, Hangauer DG: Design of a selective insulin receptor tyrosine kinase inhibitor and its effect on glucose uptake and metabolism in intact cells. Biochemistry 1989, 28 : 5694-5701

13. Rikhof B, Van der Graaf WT, Meijer C, Le PT, Meersma GJ, De Jong S, Fletcher JA, Suurmeijer AJ: Abundant Fas expression by gastrointestinal stromal tumours may serve as a therapeutic target for MegaFasL. Br J Cancer 2008, 99:1600-1606

14. Demetri GD, Benjamin RS, Blanke CD, Blay JY, Casali P, Choi $H$, Corless CL, Debiec-Rychter M, DeMatteo RP, Ettinger DS, Fisher GA, Fletcher CD, Gronchi A, Hohenberger P, Hughes M, Joensuu $H$, Judson I, Le Cesne A, Maki RG, Morse M, Pappo AS, Pisters PW, Raut CP, Reichardt P, Tyler DS, Van den Abbeele AD, Von Mehren M, Wayne JD, Zalcberg J, NCCN Task Force: NCCN Task Force report: management of patients with gastrointestinal stromal tumor (GIST)update of the NCCN clinical practice guidelines. J Natl Compr Canc Netw 2007, 5 Suppl 2:S1-S29

15. Van Doorn J, Gilhuis HJ, Koster JG, Wesseling P, Reddingius RE, Gresnigt MG, Bloemen RJ, Van Muijen GN, Van Buul-Offers SC: Differential patterns of insulin-like growth factor-I and -II mRNA expression in medulloblastoma. Neuropathol Appl Neurobiol 2004, 30: 503-512

16. Han VK, Bassett N, Walton J, Challis JR: The expression of insulin-like growth factor (IGF) and IGF-binding protein (IGFBP) genes in the human placenta and membranes: evidence for IGF-IGFBP interactions at the feto-maternal interface. J Clin Endocrinol Metab 1996 81:2680-2693

17. El-Badry OM, Minniti C, Kohn EC, Houghton PJ, Daughaday WH, Helman LJ: Insulin-like growth factor II acts as an autocrine growth and motility factor in human rhabdomyosarcoma tumors. Cell Growth Differ 1990, 1:325-331

18. Duguay SJ, Jin $Y$, Stein J, Duguay AN, Gardner P, Steiner DF: Post-translational processing of the insulin-like growth factor-2 pre- cursor. Analysis of O-glycosylation and endoproteolysis. J Biol Chem 1998, 273:18443-18451

19. Diaz LE, Chuan YC, Lewitt M, Fernandez-Perez L, Carrasco-Rodriguez S, Sanchez-Gomez M, Flores-Morales A: IGF-II regulates metastatic properties of choriocarcinoma cells through the activation of the insulin receptor. Mol Hum Reprod 2007, 13:567-576

20. Rose PP, Carroll JM, Carroll PA, DeFilippis VR, Lagunoff M, Moses AV, Roberts CT, Früh K: The insulin receptor is essential for virusinduced tumorigenesis of Kaposi's sarcoma. Oncogene 2007, 26: 1995-2005

21. Duensing A, Medeiros F, McConarty B, Joseph NE, Panigrahy D, Singer S, Fletcher CD, Demetri GD, Fletcher JA: Mechanisms of oncogenic KIT signal transduction in primary gastrointestinal stromal tumors (GISTs). Oncogene 2004, 23:3999-4006

22. Zhu MJ, Ou WB, Fletcher CD, Cohen PS, Demetri GD, Fletcher JA: KIT oncoprotein interactions in gastrointestinal stromal tumors: therapeutic relevance. Oncogene 2007, 26:6386-6395

23. ElmLinger MW, Rauschnabel U, Koscielniak E, Weber K, Ranke MB: Secretion of noncomplexed 'Big' (10-18 kD) forms of insulin-like growth factor-Il by 12 soft tissue sarcoma cell lines. Horm Res 1999 52:178-185

24. Sun Y, Gao D, Liu Y, Huang J, Lessnick S, Tanaka S: IGF2 is critical for tumorigenesis by synovial sarcoma oncoprotein SYT-SSX1. Oncogene 2006, 25:1042-1052

25. Avnet S, Sciacca L, Salerno M, Gancitano G, Cassarino MF, Longhi A, Zakikhani M, Carboni JM, Gottardis M, Giunti A, Pollak M, Vigneri R, Baldini N: Insulin receptor isoform A and insulin-like growth factor II as additional treatment targets in human osteosarcoma. Cancer Res 2009, 69:2443-2452

26. Tarn C, Rink L, Merkel E, Flieder D, Pathak H, Koumbi D, Testa JR, Eisenberg B, Von Mehren M, Godwin AK: Insulin-like growth factor 1 receptor is a potential therapeutic target for gastrointestinal stromal tumors. Proc Natl Acad Sci USA 2008, 105:8387-8392

27. Agaram NP, Laquaglia MP, Ustun B, Guo T, Wong GC, Socci ND, Maki RG, DeMatteo RP, Besmer P, Antonescu CR: Molecular characterization of pediatric gastrointestinal stromal tumors. Clin Cancer Res 2008, 14:3204-3215

28. Janeway KA, Zhu MJ, Barretina J, Perez-Atayde A, Demetri GD, Fletcher JA: Strong expression of IGF1R in pediatric gastrointestinal stromal tumors without IGF1R genomic amplification. Int J Cancer 2010, 127:2718-2722

29. Pantaleo MA, Astolfi A, Di Battista M, Heinrich MC, Paterini P, Scotlandi K, Santini D, Catena F, Manara MC, Nannini M, Maleddu A, Saponara M, Lolli C, Formica S, Biasco G: Insulin-like growth factor 1 receptor expression in wild-type GISTs: a potential novel therapeutic target. Int J Cancer 2009, 125:2991-2994

30. Braconi C, Bracci R, Bearzi I, Bianchi F, Sabato S, Mandolesi A, Belvederesi L, Cascinu S, Valeri N, Cellerino R: Insulin-like growth factor (IGF) 1 and 2 help to predict disease outcome in GIST patients. Ann Oncol 2008, 19:1293-1298

31. Frasca F, Pandini G, Scalia P, Sciacca L, Mineo R, Costantino A, Goldfine ID, Belfiore A, Vigneri R: Insulin receptor isoform A, a newly recognized, high-affinity insulin-like growth factor II receptor in fetal and cancer cells. Mol Cell Biol 1999, 19:3278-3288

32. Bauer S, Duensing A, Demetri GD, Fletcher JA: KIT oncogenic signaling mechanisms in imatinib-resistant gastrointestinal stromal tumor: pl3-kinase/AKT is a crucial survival pathway. Oncogene 2007, 26:7560-7568

33. Rossi F, Ehlers I, Agosti V, Socci ND, Viale A, Sommer G, Yozgat Y, Manova K, Antonescu CR, Besmer P: Oncogenic Kit signaling and therapeutic intervention in a mouse model of gastrointestinal stromal tumor. Proc Natl Acad Sci USA 2006, 103:12843-12848

34. Ou WB, Zhu MJ, Demetri GD, Fletcher CD, Fletcher JA: Protein kinase $\mathrm{C}$-theta regulates KIT expression and proliferation in gastrointestina stromal tumors. Oncogene 2008, 27:5624-5634

35. Steigen SE, Schaeffer DF, West RB, Nielsen TO: Expression of insulin-like growth factor 2 in mesenchymal neoplasms. Mod Pathol 2009, 22:914-921

36. Corless CL, McGreevey L, Haley A, Town A, Heinrich MC: KIT mutations are common in incidental gastrointestinal stromal tumors one centimeter or less in size. Am J Pathol 2002, 160:1567-1572

37. Kawanowa K, Sakuma Y, Sakurai S, Hishima T, Iwasaki Y, Saito K, Hosoya Y, Nakajima T, Funata N: High incidence of microscopic gastrointestinal stromal tumors in the stomach. Hum Pathol 2006 , 37:1527-1535 
38. Agaimy A, Wunsch PH, Hofstaedter F, Blaszyk H, Rümmele P, Gaumann A, Dietmaier W, Hartmann A: Minute gastric sclerosing stromal tumors (GIST tumorlets) are common in adults and frequently show C-KIT mutations. Am J Surg Pathol 2007, 31:113-120

39. Hartog H, Wesseling J, Boezen HM, Van der Graaf WT: The insulinlike growth factor 1 receptor in cancer: old focus, new future. Eur J Cancer 2007, 43:1895-1904
40. Feng Y, Zhu Z, Xiao X, Choudhry V, Barrett JC, Dimitrov DS: Novel human monoclonal antibodies to insulin-like growth factor (IGF)-II that potently inhibit the IGF receptor type I signal transduction function. Mol Cancer Ther 2006, 5:114-120

41. Steller MA, Delgado CH, Bartels CJ, Woodworth CD, Zou Z: Overexpression of the insulin-like growth factor-1 receptor and autocrine stimulation in human cervical cancer cells. Cancer Res 1996, 56:1761-1765 